\title{
Preventive System of Hospitalism Syndrome in Early Children with Cerebral Palsy
}

\section{Система профілактики синдрому госпіталізму в дітей раннього віку з ДЦП}

\author{
Liliia Rudenko \\ Dr. in Psychology, Professor, Head of the Department of Spe- \\ cial Psychology and Medicine, National Pedagogical Drahomanov \\ University, Kyiv (Ukraine) \\ ORCID ID: https://orcid.org/0000-0003-1655-5708 \\ Scopus Author ID: 77214607047 \\ E-mail: Lilianic1962@gmail.com

\section{Лілія Руденко} \\ Доктор психологічних наук, професор, завідувач кафедри \\ спеціальної психології і медицини, Національний педагогічний \\ університет імені М.П. Драгоманова, м. Київ (Україна)

\section{Tetiana Sniatkova} \\ Postgraduate Student, Department of Special Psychology and \\ Medicine, National Pedagogical Drahomanov University, Kyiv \\ (Ukraine) \\ ORCID ID: https://orcid.org/0000-0003-3374-3532 \\ E-mail: snyatkova74@ukr.net
}

\section{Тетяна Сняткова}

Аспірант кафедри спеціальної психології і медицини, Національний педагогічний університет імені М.П. Драгоманова, м. Київ (Україна)

Address for correspondence, e-mail: kpnu_lab_ps@ukr.net Copyright: (C) Rudenko Liliia, Sniatkova Tetiana

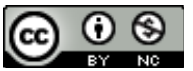

The article is licensed under CC BY-NC 4.0 International (https://creativecommons.org/licenses/by-nc/4.0/)

(C) Rudenko Liliia, Sniatkova Tetiana

DOI (article): https://doi.org/10.32626/2227-6246.2021-53.235-257 
DOI: https://doi.org/10.32626/2227-6246.2021-53

2021. випУск 53

The contribution of the author: Rudenko L. $-50 \%$, Sniatkova T. $-50 \%$.

Авторський внесок: Руденко Л. $-50 \%$, Сняткова Т. $-50 \%$.

\section{ABSTRACT}

The preventive system of hospitalism syndrome in young children with cerebral palsy includes primary, secondary and tertiary prevention, which are interrelated and ensure its successful functioning.

The aim of the research is to substantiate the peculiarities of preventive system of hospitalism syndrome in young children with cerebral palsy.

To achieve this goal, we used the following research methods: theoretical analysis and synthesis of the main regulations of psychological and pedagogical science on the problem of occurrence and prevention of hospitalism syndrome in young children with cerebral palsy; study of psychological principles of preventive work with young children with cerebral palsy; systematization of the results of scientific and theoretical analysis of the features of preventive work with young children with cerebral palsy.

Results of the research. We found that primary prevention provides active work with young children with cerebral palsy before the hospitalization symptoms' onset in order to prevent its occurrence. Secondary prevention includes the teamwork of various specialists, aimed at preventing the exacerbation of hospitalization in children, when its onsets are already present. Tertiary prevention is aimed at preventing the relapse of hospitalism against the background of the reconditioning of cognitive and social activity of young children with cerebral palsy. In accordance with the objectives of the research, a model of the preventive system of the syndrome of hospitalism in young children with cerebral palsy, we identified directions, conditions and areas of implementation of primary, secondary and tertiary prevention. In the process of substantiation of the prevention system, we indicated the specialists of different profiles perform the main activities within the primary, secondary and tertiary prevention of hospitalism syndrome in young children with cerebral palsy.

Conclusions. The main condition for the success of the preventive system of hospitalization in young children with cerebral palsy is a systematic approach to its implementation, consistent implementation of the tasks of primary, secondary and tertiary prevention.

Key words: hospitalism, young children, cerebral palsy, preventive work, early age.

(C) Rudenko Liliia, Sniatkova Tetiana

DOI (article): https://doi.org/10.32626/2227-6246.2021-53.235-257 


\section{Introduction}

The relevance of preventive work with young children with cerebral palsy is primarily associated with the worrying trend of a general decline in the birth rate of healthy children nowadays. Through the significant percentage of children born with cerebral palsy, modern psychological and pedagogical science pays much attention to the study of its causes, various forms of care, psychological support of the child and his family, who faced the problem of raising a child with special needs and disorders of psychophysical development.

Nevertheless, there is little research devoted to studying the psychological development of children with cerebral palsy during their long-term treatment in various medical institutions. Separation from the mother or a substitute effects on children so, that leads to sensory and emotional deprivation, imbalances of emotional ties with beloved ones, exacerbates psycho-emotional and motor development disorders, which may further be manifested as hospital syndrome. The foreign psychological literature (J. Bowlby, J. Langmeier and Z. Matejcek, K. Horney) considered the problem of hospitalism in young children through the prism of maternal (emotional) deprivation, and requires a timely solution, prevention of exacerbation of its consequences, which can lead to disorders of socialization and adaptation of the child in society (Боулби, 2004: 73-75; Лангмейер, 2004: 107; Хорни, 2002: 127).

Ukrainian scientists (N. Dmytriyuk, I. Krupnyk, I. Manokhina, J. Petrochko etc.) analyze the peculiarities of the emergence and overcoming of symptoms of mental deprivation, which, in their opinion, occurs in orphans, children deprived of parental care, who are for a long time separated from close people (Дмитріюк, 2015: 130; Крупник, 2012: 160; Манохіна, 2012: 106; Петрочко, 2010: 73).

We consider the syndrome of hospitalism as a deterioration of health and developmental disorders (mental, intellectual, emotional, speech, physical) due to separation of the child

(C) Rudenko Liliia, Sniatkova Tetiana DOI (article): https://doi.org/10.32626/2227-6246.2021-53.235-257 
DOI: https://doi.org/10.32626/2227-6246.2021-53

2021. випуск 53

from the mother or a substitute, and not meeting the basic needs of treatment, care, communication, complete development. Depending on child's deprivation and unmet needs, he (she) shows symptoms of maternal, sensory, communicative, emotional, social deprivation.

The problem of prevention of hospitalization in young children with cerebral palsy is due to the long stay of these children while treatment in various medical institutions and the high risk of this syndrome due to separation from beloved ones (mother or substitute).

At the same time, in psychological science, researchers gave insufficient attention to the study of hospitalism. Generally, they reveal its definitions, causes, directions of correctional work with children in the conditions of hospitalism (N. Bocharina, N. Dmitriyuk, I. Krupnyk, I. Mamawchuk, J. Petrochko etc.) (Бочаріна, 2016: 399; Дмитріюк, 2015: 130; Крупник, 2012: 160; Мамайчук, 2001: 217; Петрочко, 2010: 73).

In the research, V. Havrylkevych, E. Evsegneeva, T. Zhuravel, P. Krasnova, O. Prykhodko, I. Parfanovych, A. Pevneva, R. Rakhmanov, N. Shevchenko and others pay attention to the principles of providing psychological assistance to children with cerebral palsy (Havrylkevych, 2021: 169; Евсегнеева, 2020: 815; ЖЖуравель, 2013: 86; Краснова, 2018: 101; Приходько, 2008: 39; Парфанович, 2009: 37; Певнева, 2019: 605; Рахманов, 2016: 77; Шевченко, 2019: 354). Despite substantial research by the following scientists, the problem of preventive work with young children with cerebral palsy that has the syndrome of hospitalization, is insufficiently considered.

The purpose of the research is to ground the peculiarities of the implementation of preventive system of hospitalism syndrome in young children with cerebral palsy.

\section{The tasks of the research}

1. To analyze the methodological principles of the system of primary, secondary and tertiary prevention of hospitalism (c) Rudenko Liliia, Sniatkova Tetiana

DOI (article): https://doi.org/10.32626/2227-6246.2021-53.235-257 
syndrome in young children with cerebral palsy (determine the tasks, conditions and areas of implementation).

2. To develop a model of preventive system of hospitalism syndrome in young children with cerebral palsy, including primary, secondary, tertiary prevention.

3. To reveal features of preventive system's realization of a syndrome of hospitalism at children of early age with cerebral palsy, to distinguish the basic activity's directions of various team of specialists within primary, secondary and tertiary prevention with these children.

\section{Research methods and techniques}

In researching the peculiarities of the preventive system of hospitalism syndrome in young children with cerebral palsy, we used the following methods: theoretical analysis and synthesis of the main regulations of psychological and pedagogical science on the problem of onset and prevention of hospital syndrome in young children with cerebral palsy; study of psychological principles of preventive work with young children with cerebral palsy in terms of deprivation of their basic needs; systematization of the results of scientific and theoretical analysis to implement the features of the system of preventive work with young children with cerebral palsy, including primary, secondary and tertiary links.

\section{Results and discussions}

Many scientists in the field of psychology, pedagogy, sociology, medicine and others studied the prevention as a system of measures to prevent various negative phenomena and processes. According to T. Zhuravel, in the general sense prevention is defined as a set of measures aimed at preventing mental and behavioral disorders, maintaining mental well-being; prevention of the disease and its relapse, as well as measures aimed at preventing the transition of the disease to its chronic forms (Журавель, 2013: 86).

(C) Rudenko Liliia, Sniatkova Tetiana

DOI (article): https://doi.org/10.32626/2227-6246.2021-53.235-257 
Primary prevention: a set of measures aimed at preventing the negative impact of biological, psychological, socio-pedagogical and other factors that may cause the formation of disorders, diseases.

Tasks: improvement, increase of efficiency of the active, constructive behavioral strategies used by the child; increasing the potential of personal resources.

Directions: providing a sufficient number of sensory activities and their variability; enabling motor activity; creating the necessary conditions for the structuring of the world of incentives; providing an opportunity to establish an intimate emotional relationship with the mother or substitute.

Conditions: the sequence of assimilation of sensory standards by children, and the gradual complication of cognitive tasks; close connection of sensory development with other types of productive activities; systematic, repetition and reinforcement of mastered sensory standards, acquired communication skills and abilities; enriching and deepening the sensory experience of children by forming in them a wide world orientation.

Scope of implementation: at home (in children's homes) and in medical institutions; carried out by parents or substitutes. nsvchologists and social. teachers. emnlovees of medical institutions.

Secondary prevention: a set of measures that includes active overcoming of the identified symptoms of hospitalization and prevention of their relapse; is an individual work that takes into account the existing symptoms and goals to correct them.

Objectives: to limit the spread of certain negative phenomena, includes both socio-psychological and medical measures of a non-specific nature; prevention of exacerbation of the syndrome of hospitalism, when its onsets are already present.

Areas: the formation of interaction skills with adults, the development of communication skills, corrective work to overcome maladapted behavior, the correction of disorders in the development of the cognitive area.

Conditions: inclusion of medical workers and psychologist of the medical institution in the provision of psychoprophylactic and correctional care to young children with cerebral palsy; socio-psychological direction of preventive work on the formation of children's communication skills, correction of emotional and personal development disorders; active use of moving and cognitive tasks and games that involve expanding the horizons of the child, the development of his (her) intellectual and communicative abilities, improving the motor activity of children with cerebral palsy.

Scope of implementation: in medical and social institutions; carried out by a team of various specialists with the participation of the child's parents or substitutes.

Tertiary prevention: a set of social, educational and medical-psychological measures aimed at restoring the personal and social status of the child, his (her) return to the family, society, active work.

Tasks: prevention or mitigation of the disease, prevention of psychosomatic defects, the phenomena of hospitalism, its disability; adaptation of a child with cerebral palsy to the conditions of the external environment, restoration of his (her) motivation to activity, work, to an active way of life, interpersonal relations; stimulation of social activity of children by various methods.

Directions: formation of social and household skills; formation of adequate cognitive activity; formation of communication skills; development of the cognitive area; emotional and personal development.

Conditions: close cooperation of the team of various specialists with the parents or substitutes of these children; organization of the correct attitude to these children by the environment - parents, educators, peers, society; conducting educational work with parents, substitutes, and the team of various specialists.

Scope of implementation: in medical institutions and at home (in children's homes); carried out by parents or substitutes, psychologists and social educators, medical workers, institutions.

The main condition for the success of the system of prevention of hospitalization in young children with cerebral palsy is a systematic approach to its implementation, consistent implementation of the tasks of primary, secondary and tertiary prevention.

\section{Fig. 1. The preventive system of hospitalism syndrome in children with cerebral palsy}

\section{(C) Rudenko Liliia, Sniatkova Tetiana}

DOI (article): https://doi.org/10.32626/2227-6246.2021-53.235-257 
The modern psychological and pedagogical practice allocates primary, secondary and tertiary prevention, which we consider as a part of a single system of work to prevent and overcome the syndrome of hospitalism in young children with cerebral palsy (Fig. 1).

Primary prevention is often understood by scientists (T. Zhuravel, I. Parfanovych etc.) as a set of measures aimed at preventing the negative impact of biological, psychological, socio-pedagogical and other factors that can cause the formation of disorders, diseases. The primary preventive work with young children with cerebral palsy in hospital is to fullfill the child's day with interesting activities and plays, while providing it with sensory activities, sufficient information content and communication with adults and children (Журавель, 2013: 86; Парфанович, 2009: 37).

Important conditions for the implementation of the tasks of primary prevention of hospitalization in children with cerebral palsy are: the sequence of acquaintance of children with the sensory properties of objects, their assimilation of sensory standards and the gradual complication of cognitive tasks; close connection of sensory development of children with other types of productive activities (with play, communication, etc.); regularity of classes, repetition and reinforcement of mastered sensory standards, acquired communication skills and abilities; enriching and deepening the sensory experience of children by forming in them a wide orientation in the world around them.

Also, the conditions of primary prevention of the syndrome of hospitalism include: conducting various types of play activities with children, which will meet their need for physical activity (due to the body's ability - to turn his (her) head, raise his (her) arms); providing an opportunity to establish an intimate emotional relationship with the mother or a substitute (involving the mother in communicating with children, singing songs, learning poems, conducting certain elements of psycho-gymnastic exercises).

(C) Rudenko Liliia, Sniatkova Tetiana

DOI (article): https://doi.org/10.32626/2227-6246.2021-53.235-257 
DOI: https://doi.org/10.32626/2227-6246.2021-53

2021. випУСК 53

As an example of enriching the sensory experience of children with cerebral palsy, they are first introduced to sensory standards, offered to group homogeneous objects by different sensory qualities, then they need to correlate heterogeneous objects in size, shape, color, taking them into account in elementary productive activities (manipulation of these objects). For example, first the child is given a cube, later offered several cubes of different colors and sizes, later invited to pick up a red cube.

The combination of preventive work to prevent hospitalism syndrome in children with cerebral palsy in relation to their sensory development with different types of productive activities of children (play, communication), adult (mother or member of the team of specialists) create conditions for comprehensive formation, pay attention to fine motor skills, game skills, cognitive abilities. We consider the right opinion of V. Kashchuk, who emphasizes «realizing the importance and complexity of the tasks of sensory development of children, it is worth focusing on the following activities with children: the formation of a system of sensory standards; development of fine motor skills of the hand; development of their mental processes; development of mental operations; activation of children's vocabulary; formation of communicative abilities; creation of a development environment; formation of motor activity and development of coordination of movements; formation of self-regulation skills, etc» (Кащук, 2015). It is important to involve young children with cerebral palsy in play, learning, communication, art and craft (painting, music, dance), physical activity within their abilities. Of course, children with cerebral palsy do not have the same abilities as their children of the same age with normal development, but even listening to an adult, participating in various types of communicative and musical games, performing psychogymnastic elements of exercises to music, perception of colorful activities has a beneficial effect on their cognitive development, enriches the system of (c) Rudenko Liliia, Sniatkova Tetiana

DOI (article): https://doi.org/10.32626/2227-6246.2021-53.235-257 
sensory standards. And friendly, caring communication of an adult with a child creates opportunities for the formation of an emotional connection with him (her), the child's feeling of caring for himself (herself), the idea that he (she) is loved and appreciated.

We consider regularity to be an important condition for the primary prevention of hospitalization syndrome, because early age is characterized by rapid rates of development, and therefore it is worth paying attention at this stage to everything that can be corrected or prevented. At the same time, as V. Kashchuk testifies, "the task of repeating the acquired skills and abilities should be different from the main task previously performed. The simple repetition of the same tasks can lead to mechanical, situational memorization, rather than to the progressive development of mental activity in young children» (Кащук, 2015). Therefore, to prevent hospitalization in the process of sensory development of children, it is necessary to select similar tasks that differ from the previously mastered, but during which you can apply the acquired skills and abilities to develop children's horizons.

It is important to pay attention to the wide orientation of children with cerebral palsy in the environment. To do this, along with tasks to enrich the sensory development of children, it is advisable to offer them exercises that involve listening carefully to adult language (telling fairy tales, short stories, poems, introducing children to the seasons, weather phenomena), develop children's musical hearing (sing children's songs, lullabies), gradually develop musculoskeletal sensitivity (perform various exercises that are allowed for various disabilities of children with cerebral palsy). For example, in the development of musculoskeletal sensitivity, you can use the techniques of drawing in the air, when an adult takes a child's hand in his (hers) and helps him (her) draw, draw the outline of the image on paper or a cube on the table. Using the technique of joint drawing, the adult asks the child about

(C) Rudenko Liliia, Sniatkova Tetiana DOI (article): https://doi.org/10.32626/2227-6246.2021-53.235-257 
DOI: https://doi.org/10.32626/2227-6246.2021-53

2021. випуск 53

the colors of the objects and phenomena they will draw (sun is yellow, flower is red, grass is green), their location (sun at the top, grass at the bottom).

Primary prevention of hospitalism syndrome should be carried out at home by the parents of a young child with cerebral palsy before hospitalization in a medical institution for treatment or by psychologists and educators who raise these children in institutions for children deprived of parental care. Also, primary prevention should be implemented by specialists (psychologists, medical and social psychologists and educators) in institutions where young children with cerebral palsy receive medical care, undergo rehabilitation.

Secondary prevention aims to limit the spread of certain negative phenomena, includes both socio-psychological and non-specific medical measures (Парфанович, 2009: 37). Аccording to its focus, the secondary prevention of hospitalism syndrome in young children with cerebral palsy is individual for a particular child.

During the secondary prevention of hospitalization symptoms when they are confirmed in children with cerebral palsy, the psychologist performs the following types (directions) of work: develops skills of interaction with adults, develops communication skills, conducts corrective work to overcome maladapted behavior, correction of cognitive disorders.

It is noted that the primary prevention of hospitalization involves active work with children with cerebral palsy before the onset of its symptoms in order to prevent its occurrence. And secondary prevention of hospitalism includes the work of a team of specialists in the prevention of exacerbation of the syndrome of hospitalism, when its onsets are already present.

According to I. Parfanovych, the implementation of secondary prevention programs should be carried out by specially trained professionals, psychotherapists, psychologists, social workers, teachers and a network of non-professionals - parents C Rudenko Liliia, Sniatkova Tetiana

DOI (article): https://doi.org/10.32626/2227-6246.2021-53.235-257 
of children with cerebral palsy, members of self- and mutual aid groups, counselors. The effect of secondary prevention programs is faster than that of primary (Парфанович, 2009: 37).

According to I. Mamaichuk, «rehabilitation specialists, psychologists and social pedagogues together with parents should carry out the necessary preventive and corrective work for children with cerebral palsy who have onsets of hospitalism. Such work should be aimed at the general development of the child, preventing the emergence of undesirable personality traits, such as stubbornness, irritability, tearfulness, uncertainty; on the formation of cognitive activity, the satisfaction of various interests, because many children with cerebral palsy have potentially preserved prerequisites for the development of intellectual processes (thinking, memory)» (Мамайчук, 2001: 217).

According to $\mathrm{O}$. Viktorovich, the basis of secondary prevention of hospitalism is a systematically directed by psychological and pedagogical correction. The psychologist needs constantly to deal with a small patient, to entrust him with at least minimal tasks that help train memory, thinking and attention (Викторович, 2018). Medical staff can also be appropriate to interact with young children, performing with them psycho-correctional exercises and tasks, for example, to create trusting communication to use soothing gestures, pleasant intonation in conversation, hugs, stroking the child. To correct emotional disorders and onsets of maladaptive behavior of young children with cerebral palsy (introversion, alienation from the outside world, or vice versa violent reaction, stubbornness, unwillingness to receive treatment, scattering of things) psychologist with health professionals can use special techniques: reading author's therapeutic tales (according to the problem); involvement of children in a game situation with toys, cubes, various natural material that interests children; storytelling about various events and phenomena of the environment.

(C) Rudenko Liliia, Sniatkova Tetiana

DOI (article): https://doi.org/10.32626/2227-6246.2021-53.235-257 
DOI: https://doi.org/10.32626/2227-6246.2021-53

2021. випуск 53

Thus, special exercises and techniques, tasks used in secondary preventive and corrective work to overcome the onsets of hospitalization in children with cerebral palsy, aimed at reducing children's anxiety, creating a trusting atmosphere of communication with adults, providing conditions for cognitive, emotional and socio-psychological development. Cognitive exercises aimed at developing children's attention, thinking and memory are effective; relaxation exercises (relaxation to musical accompaniment with stroking, hugging an adult); art-therapeutic exercises that ensure the development of children's creative abilities, create a sense of psychological comfort, promote the harmonious development of the child's personality; reading and discussion of metaphorical and therapeutic fairy tales, which promotes the development of ideas about the world around, activation of moral and spiritual development of the child, who gets acquainted with the norms of behavior and moral values of society (according to the chosen fairy tale and the problem solved in it).

We also want to emphasize the need to create conditions for motor activity of the child, inviting him to participate in games (raise the handles, shake his head, show how a butterfly flies, imagine a bee and reproduce its sounds, show how a cat stretches in the sun, etc.). This is how secondary preventive work to overcome the syndrome of hospitalization in young children with cerebral palsy expands children's understanding of the world around them, increases interest in learning about natural phenomena and weather, the peculiarities of relationships between people (for example, fairy tale characters).

According to $\mathrm{O}$. Viktorovich, as a result of such preventive work it is possible to achieve the formation of a favorable emotional state in a child. She gets rid of the worries and anxieties associated with being in a hospital or an orphanage. In complex cases of hospitalization syndrome, a child with cerebral palsy may need drug therapy aimed at improving emotional stability and stimulating the development of cognitive functions (ВикC Rudenko Liliia, Sniatkova Tetiana

DOI (article): https://doi.org/10.32626/2227-6246.2021-53.235-257 
торович, 2018). However, it is impossible to overcome the syndrome of hospitalism only with drug therapy, so we attach great importance to the active preventive and corrective work of a psychologist with young children with cerebral palsy.

The conditions for the effective implementation of secondary prevention of hospitalism syndrome include: the inclusion of medical workers and psychologists of the medical institution in the provision of psychoprophylactic and correctional care for young children with cerebral palsy; socio-psychological direction of preventive work on the formation of children's communication skills, correction of disorders of emotional and personal development (excitability, stubbornness, negativism, infantilism, etc.); active use of moving and cognitive tasks and games that involve expanding the horizons of the child, the development of its intellectual and communicative abilities, improving the motor activity of children with cerebral palsy.

Tertiary prevention is defined as a set of social, educational and medical-psychological measures aimed at restoring the personal and social status of the child, his return to the family, society, activities. Tertiary prevention among young children with cerebral palsy is mainly medical and social, individual and aimed at preventing the transition of the existing disease to its more severe form, the consequences in the form of persistent maladaptation. The role of professionals - psychotherapists, therapists, social workers and psychologists, as well as non-professionals - counselors members of social support groups and communities (Парфанович, 2009: 38) is growing sharply in the implementation of tertiary prevention. Note that tertiary prevention of hospitalism is aimed at preventing relapse when the syndrome has been overcome to prevent relapse.

According to I. Savenkova, the main tasks of tertiary prevention are the elimination or mitigation of the disease, prevention of the formation of psychosomatic defects, the phenomena of hospitalism, its disability; adaptation of a child with

(C) Rudenko Liliia, Sniatkova Tetiana DOI (article): https://doi.org/10.32626/2227-6246.2021-53.235-257 
DOI: https://doi.org/10.32626/2227-6246.2021-53

2021. випуск 53

cerebral palsy to the conditions of the external environment, restoration of his motivation to activity, work, to an active way of life, interpersonal relations; stimulation of children's social activity by various methods (Савенкова, 2014: 315).

The main areas of tertiary preventive and corrective work of a psychologist with young children with cerebral palsy are: the formation of social skills; formation of adequate cognitive activity; formation of communication skills; development of the cognitive sphere; emotional and personal development. The choice of the direction of preventive work with a child with cerebral palsy depends on the general objectives of its individual development and correction of psycho-emotional and intellectual, personal disorders, as well as the distribution of functional responsibilities between a team of specialists.

The conditions for the success of tertiary prevention of hospitalism syndrome in young children with cerebral palsy include close cooperation of a team of specialists with the parents of these children, or persons who replace them. It is through the group influence of parents and a team of doctors, teachers, speech therapists on a sick child can achieve sustainable improvement of its physical condition and prevent the formation of hospitalization syndrome, promote rapid recovery of impaired sensory, personal, psycho-emotional development.

We find confirmation of this opinion in R. Rakhmanov, who notes: "It is worth remembering that medical and social rehabilitation of children with cerebral palsy is a long-term problem that should be carried out in the most achievable conditions, under the supervision of specialists, inpatient or outpatient with the participation of the child's parents or persons who replace them» (Рахманов, 2016: 77). This not only helps to optimize the mental state of children, overcome their anxiety, aggression, depressive moods, increase cognitive activity, socialization, but also allow adults to see these changes, feel hope for improvement, understand the optimistic prognosis of treatment and rehabilitation of children with cerebral palsy. (C) Rudenko Liliia, Sniatkova Tetiana

DOI (article): https://doi.org/10.32626/2227-6246.2021-53.235-257 
A very important condition that contributes to the success of tertiary prevention and rehabilitation work with children with cerebral palsy, according to I. Savenkova, is the organization of the right attitude to these children by the environment - parents, educators, children of the same age, society (Савенкова, 2014: 315-316).

In addition to these areas of preventive work with young children with cerebral palsy to prevent and overcome the syndrome of prevention, we attach great importance to educational work with parents, substitutes, teachers and psychologists of orphanages, medical staff (doctors, nurses, social educators), where children with cerebral palsy receive long-term medical care. Such forms of work as lectures, educational and methodical seminars, individual and group consultations, workshops, during which the issues of hospitalism syndrome in children with cerebral palsy are covered, are expedient for carrying out with members of the team of various specialists working with children with cerebral palsy. Long-term treatment in various institutions, the conditions of its prevention, means and methods of work on its prevention and overcoming the consequences must be paid attention to. Specialists must be firmly aware of the harmful effects of hospital syndrome for young children with cerebral palsy, create the most comfortable conditions for these children in medical institutions, conduct targeted work to prevent hospitalization, as well as learn to work on this problem, carry out educational work to disseminate necessary knowledge among colleagues, parents of children with cerebral palsy.

In our opinion, an important condition for the success of the entire system of preventive work with young children with cerebral palsy in hospital is a systematic approach to its implementation, the consistent implementation of primary, secondary and tertiary prevention. Systematic stages of prevention of hospitalization in young children with cerebral palsy requires mandatory compliance with the sequence of care, namely: pre-

(C) Rudenko Liliia, Sniatkova Tetiana DOI (article): https://doi.org/10.32626/2227-6246.2021-53.235-257 
DOI: https://doi.org/10.32626/2227-6246.2021-53

2021. випуск 53

vention of hospitalization syndrome; active preventive work to prevent its exacerbation in children who have already certain onsets; prevention of relapse of hospitalism, restoration of cognitive and social activity, optimization of various spheres of development in children who have overcome it. With the elimination of any stage and violation of the system of preventive work with young children with cerebral palsy, the possibility of achieving a successful result in preventing their hospitalism syndrome is significantly reduced.

\section{Conclusions}

The system of hospitalization prevention includes three interrelated links: primary prevention (before the onset of symptoms of hospitalism, aimed at preventing its occurrence); secondary (when there are onsets of hospitalism, aims to prevent its exacerbation); tertiary (when the onsets of hospitalism are overcome, organized to prevent relapse). In accordance with the purpose and objectives of the study, a model of the preventive system of hospital syndrome in children with cerebral palsy was built, which considered the definition and objectives, identified areas, conditions and areas of primary, secondary and tertiary prevention. In the process of substantiation of the prevention system, it is indicated which of the team of various specialists performs the main activities within the primary, secondary and tertiary prevention of hospitalism syndrome in young children with cerebral palsy.

An important condition for the success of the entire prevention system is the systematic stages of providing care to a child with cerebral palsy, which includes mandatory compliance with the following sequence: prevention of hospitalization syndrome; active preventive and corrective work to overcome it and prevent exacerbation in certain onsets; restoration of cognitive and social activity, social adaptation to society, optimization of various spheres of development in children with cerebral palsy. With the loss of one of the links (primary, C Rudenko Liliia, Sniatkova Tetiana

DOI (article): https://doi.org/10.32626/2227-6246.2021-53.235-257 
secondary or tertiary prevention), the success of preventive work to prevent hospitalization in young children with cerebral palsy is significantly reduced. Therefore, the prevention of this syndrome in children with cerebral palsy requires a comprehensive approach and application of a system of primary, secondary and tertiary prevention.

A promising area of the study is the introduction of specific measures of the system of primary, secondary and tertiary prevention in the work of a team of various specialists with young children with cerebral palsy and determines the effectiveness of preventive activities.

\section{Literature}

Боулби Дж. Создание и разрушение эмоциональных связей. Москва : Академический проект, 2004. 232 с.

Бочаріна Н.О. Особливості розвитку особистості дитини в умовах психічної депривації. Молодий вчений, 2016, 6 (33), 398-402.

Викторович О. Госпитализм: причины и методы лечения синдрома. URL : https://mozg.expert/sindromy/gospitalizm/ (дата обращения: 17.03.2020).

Дмитріюк Н.С. Науково-практичний аспект проблеми депривованої особистості. Актуальні проблеми психологї, 2015, 1 (42), 128-133.

Евсегнеева Е.Р. Коммуникации в педиатрии - от рутинных процедур до трудных ситуаций. Психиатрия, психотерапия и клиническая психология, 2020, 11 (4), 812-820.

Журавель Т.В. Соціальна профілактика як напрям соціально-педагогічної діяльності. Соціальна педагогіка: навч. посібник / за заг. ред. О.В. Безпалько. Київ : Академвидав, 2013. С. 85-101.

Кащук В. Сутність сенсорного розвитку сучасної дитини раннього віку. Вісник Інституту розвитку дитини, 2015, 6. URL : https://ird. npu.edu.ua/q-q-36/-6 (дата звернення 15.03.2020).

Краснова П.В. Детская и подростковая психиатрия. Обзор. Психиатрия, психотерапия и клиническая психология, 2018, 9 (1), 99109.

Крупник I.P. Феномен психічної депривації та його значення в сучасному суспільстві. Проблели загальної та педагогічної психології, 2012, 14 (1), 156-163.

Лангмейер Й., Матейчек 3. Психическая депривация в детском возрасте. Прага : Мед. изд-во «Авиценум», 2004. 334 с.

(C) Rudenko Liliia, Sniatkova Tetiana

DOI (article): https://doi.org/10.32626/2227-6246.2021-53.235-257 
DOI: https://doi.org/10.32626/2227-6246.2021-53

2021. випуск 53

Мамайчук И.И. Психологическая помощь детям с проблемами в развитии. Санкт-Петербург, 2001. 420 с.

Манохіна I.B. Соціально-педагогічна робота з дітьми-сиротами та дітьми, позбавленими батьківського піклування. Дніпропетровськ, 2012. 276 c.

Парфанович I.I. Соціальна профілактика. Тернопіль : ТДПУ, 2009. $159 \mathrm{c}$.

Певнева А.Н. Динамика невротического состояния матери ребенка с церебральным параличом. Психиатрия, психотерапия и клиническая психология, 2019, 10 (4), 600-610.

Петрочко Ж⿱.В. Дитина у складних життєвих обставинах: соціально-педагогічне забезпечення прав: монографія. Рівне : Видавець О. Зень, 2010. 368 с.

Приходько О.Г. Ранняя помощь детям с церебральным параличом в системе комплексной реабилитации: монография. Санкт-Петербург : Изд-во РГПУ им. А.И. Герцена, 2008. 208 с.

Рахманов Р.В. Результати клініко-психіатричного та психологічного дослідження сімей, діти яких хворіють на дитячий церебральний параліч та аутизм, після проведення останнім психосоціальної реабілітації. Український вісник психоневрологї, 2016, 24, 1 (86), $75-78$.

Савенкова I.I. Хронопсихологічне прогнозування перебігу захворювань у психосоматичних хворих: монографія. Київ : Київ. ун-т ім. Б. Грінченка, 2014. 320 с.

Хорни К. Невротическая личность нашего времени. Санкт-Петербург : Питер, 2002. 224 с.

Шевченко Н.Ф., Маркова М.В. Сравнительный анализ особенностей проявления милосердия у медицинских работников и представителей других социономических профессий. Психиатрия, психотерапия и клиническая психология, 2019, 10 (2), 353-362.

Havrylkevych, V., Podkorytova, L., Danylchuk, L., Romanovska, L., Kravchyna, T., \& Chovgan, O. Psychological Correction of Parents' Attitude to Their Children with Special Educational Needs by Means of Art Therapy. BRAIN. Broad Research in Artificial Intelligence and Neuroscience, 2021, 12 (1), 154-171.

\section{References}

Boulbi, Dzh. (2004). Sozdaniie $i$ razrusheniie emotsionalnykh sviazei [Creation and destruction of emotional connections]. Moskva : Akademicheskii proekt [in Russian].

(C) Rudenko Liliia, Sniatkova Tetiana

DOI (article): https://doi.org/10.32626/2227-6246.2021-53.235-257 http://journals.uran.ua/index.php/2227-6246 
Bocharina, N.O. (2016). Osoblyvosti rozvytku osobystosti dytyny v umovakh psykhichnoi depryvatsii [Features of development of the child's personality in the conditions of mental deprivation]. Molodyi vchenyi - Young scientist, 6 (33), 398-402 [in Ukrainian].

Viktorovych, O. (2018). Gospitalizm: prichiny i metody lecheniia sindroma [Hospitalism: causes and methods of treatment of the syndrome]. Retrieved from https://mozg.expert/sindromy/gospitalizm/ [in Russian].

Dmytriiuk, N.S. (2015). Naukovo-praktychnyi aspekt problemy depryvovanoi osobystosti [Scientific and practical aspect of the problem of deprived personality]. Aktualni problemy psykholohii-Current problems of psychology, 1 (42), 128-133 [in Ukrainian].

Yevsegneeva, E.P. (2020). Kommunikatsii v pediatrii - ot rutinnykh protsedur do trudnykh situatsii [Communication in Pediatrics - from Routine Procedures to Difficult Situations]. Psikhiatriia, psikhoterapiia i klinicheskaia psikhologiia - Psychiatry, psychotherapy and clinical psychology, 11 (4), 812-820 [in Russian].

Zhuravel, T.V. (2013). Sotsialna profilaktyka yak napriam sotsialno-pedahohichnoi diialnosti [Social prevention as a direction of social and pedagogical activity]. O.V. Bezpalko (Ed.). Sotsialna pedahohika Social pedagogy, (pp. 85-101). Kyiv : Akademvydav [in Ukrainian].

Kashchuk, V. (2015). Sutnist sensornoho rozvytku suchasnoi dytyny rannoho viku [The essence of sensory development of a modern young child]. Visnyk Instytutu rozvytku dytyny - Bulletin of the Institute of Child Development, (Vol. 6). Retrieved from https://ird.npu.edu. ua/q-q-36/-6 [in Ukrainian].

Krasnova, P.V. (2018). Detskaia i podrostkovaia psikhiatriia. Obzor [Pediatric and adolescent psychiatry (review)]. Psikhiatriia, psikhoterapiia $i$ klinicheskaia psikhologiia - Psychiatry, psychotherapy and clinical psychology, 9 (1), 99-109 [in Russian].

Krupnyk, I.R. (2012). Fenomen psykhichnoi depryvatsii ta yoho znachennia $\mathrm{v}$ suchasnomu suspilstvi [The phenomenon of mental deprivation and its significance in modern society]. Problemy zahalnoi ta pedahohichnoi psykholohii - Problems of general and pedagogical psychology, 14 (1), 156-163 [in Ukrainian].

Langmeyer, Y., \& Mateichek, Z. (2004). Psikhicheskaia deprivatsiia $v$ detskom vozraste [Psychic deprivation in childhood]. Praga : Meditsinskoie izdatelstvo "Avitsenum» [in Russian].

Mamaichuk, I.I. (2001). Psikhologicheskaia pomoshch detiam s problemami $v$ razvitii [Psychological assistance to children with developmental problems]. Sankt-Peterburg : Rech [in Russian].

(C) Rudenko Liliia, Sniatkova Tetiana

DOI (article): https://doi.org/10.32626/2227-6246.2021-53.235-257 
DOI: https://doi.org/10.32626/2227-6246.2021-53

2021. випУСК 53

Manokhina, I.V. (2012). Sotsialno-pedahohichna robota z ditmy-syrotamy ta ditmy, pozbavlenymy batkivskoho pikluvannia [Social and pedagogical work with orphans and children deprived of parental care]. Dnipropetrovsk [in Ukrainian].

Parfanovych, I.I. (2009). Sotsialna profilaktyka [Social prevention]. Ternopil : TDPU [in Ukrainian].

Pevneva, A.N. (2019). Dinamika nevroticheskogo sostoianiia materi rebenka s tserebralnym paralichom [Dynamics of neurotic state of mother of the child with cerebral palsy]. Psikhiatriia, psikhoterapiia $i$ klinicheskaia psikhologiia - Psychiatry, psychotherapy and clinical psychology, 10 (4), 600-610 [in Russian].

Petrochko, Zh.V. (2010). Dytyna u skladnykh zhyttievykh obstavynakh: sotsialno-pedahohichne zabezpechennia prav [Child in difficult life circumstances: social and pedagogical provision of rights]. Rivne [in Ukrainian].

Prikhodko, O.G. (2008). Ranniaia pomoshch detiam s tserebralnym paralichom $v$ sisteme kompleksnoi reabilitatsii [Early assistance to children with cerebral palsy in the system of complex rehabilitation]. Sankt-Peterburg : Izdatelstvo RGPU im. A.I. Gertsena [in Russian]. Rakhmanov, R.V. (2016). Rezultaty kliniko-psykhiatrychnoho ta psykholohichnoho doslidzhennia simei, dity yakykh khvoriiut na dytiachyi tserebralnyi paralich ta autyzm, pislia provedennia ostannim psykhosotsialnoi reabilitatsii [Results of clinical-psychiatric and psychological research of families whose children suffer from cerebral palsy and autism, after the latter psychosocial rehabilitation.]. Ukrainskyi visnyk psykhonevrolohii - Ukrainian Bulletin of Psychoneurology, 24, 1 (86), 75-78 [in Ukrainian].

Savenkova, I.I. (2014). Khronopsykholohichne prohnozuvannia perebihu zakhvoriuvan u psykhosomatychnykh khvorykh [Chronopsychological forecasting of diseases in psychosomatic patients]. Kyiv : Kyiv. universytet im. B. Hrinchenka [in Ukrainian].

Khorni, K. (2002). Nevroticheskaia lichnost nashego vremeni [The neurotic personality of our time]. Sankt-Peterburg : Piter [in Russian].

Shevchenko, N.F., \& Markova, M.V. (2019). Sravnitelnyi analiz osobennostei proiavleniia miloserdiia u meditsinskikh rabotnikov i predstavitelei drugikh sotsionomicheskikh professii [Comparative Analysis of Peculiarities of Mercy Manifestations in Medical Staff and Representatives of Other Socionomic Professions]. Psikhiatriia, psikhoterapiia i klinicheskaia psikhologiia - Psychiatry, psychotherapy and clinical psychology, 10 (2), 353-362 [in Russian].

Havrylkevych, V., Podkorytova, L., Danylchuk, L., Romanovska, L., Kravchyna, T., \& Chovgan, O. (2021). Psychological Correction of (C) Rudenko Liliia, Sniatkova Tetiana

DOI (article): https://doi.org/10.32626/2227-6246.2021-53.235-257 http://journals.uran.ua/index.php/2227-6246 
DOI: https://doi.org/10.32626/2227-6246.2021-53

2021. ВИПУСК 53

Parents' Attitude to Their Children with Special Educational Needs by Means of Art Therapy. BRAIN. Broad Research in Artificial Intelligence and Neuroscience, 12 (1), 154-171.

\section{Руденко Лілія, Сняткова Тетяна. Система профілактики синдрому гос- піталізму в дітей раннього віку з ДЦП}

\section{АНОТАЦІЯ}

Система профрілактики синдрому госпіталізму в дітей раннього віку з дитячими черебральними паралічами включає первинну, вторинну й третинну профілактику, що є взаємопов'язаними ланками і забезпечують ї успішне функціонування.

Мета статmі - обгрунтувати особливості реалізації системи профілактики синдрому госпіталізму в дітей раннього віку з ДЦП.

Для досягнення зазначеної мети використано такі методи дослідження: теоретичний аналіз і синтез основних положень психолого-педагогічної науки з проблеми виникнення та профрілактики синдрому госпіталізму в дітей раннього віку з ДЦП; вивчення психологічних засад профрілактичної роботи з дітьми раннього віку з дитячими церебральними паралічами; систематизація результатів науково-теоретичного аналізу особливостей профілактичної роботи з дітьми раннього віку з ДЦП.

Результати дослідження. 3'ясовано, що первинна профрілактика передбачає активну роботу з дітьми раннього віку з дитячими церебральними паралічами до появи симптомів госпіталізму з метою запобігання його виникнення. Вторинна профрілактика включає в себе роботу команди фахівців різних профрілів, що спрямована на попередження загострення госпіталізму в дітей, коли вже наявні його прояви. Третинна профрілактика спрямована на попередження повторного виникнення госпіталізму на тлі відновлення пізнавальної та соціальної активності дітей раннього віку з ДЦП. Відповідно до завдань дослідження побудовано модель системи профрілактики синдрому госпіталізму в дітей раннього віку з ДЦП, виокремлено напрями, умови та срери реалізації заходів первинної, вторинної й третинної профрілактики. У процесі обгрунтування системи профілактики вказано, якими фрахівцями різних профілів виконуються основні напрями діяльності у межах первинної, вторинної й третинної профрілактики синдрому госпіталізму в дітей раннього віку з дитячими церебральними паралічами.

(C) Rudenko Liliia, Sniatkova Tetiana DOI (article): https://doi.org/10.32626/2227-6246.2021-53.235-257 
DOI: https://doi.org/10.32626/2227-6246.2021-53

2021. випУСК 53

Висновки. Основною умовою успішності системи профілактики госпіталізму в дітей раннього віку з ДЦП є систематичний підхід до ії проведення, послідовна реалізація завдань первинної, вторинної й третинної профрілактики.

Ключові слова: госпіталізм, діти раннього віку, дитячий параліч, профрілактична робота, ранній вік.

\section{Руденко Лилия, Сняткова Татьяна. Система профилактики синдрома госпитализма у детей раннего возраста с ДЦП}

\section{АННОТАЦИЯ}

Система профилактики синдрома госпитализма у детей раннего возраста с детскими церебральными параличами включает первичную, вторичную и третичную профилактику, которые являются взаимосвязанными звеньями и обеспечивают ее успешное функционирование.

Цель статьи - обосновать особенности реализации системы профилактики синдрома госпитализма у детей раннего возраста с ДЦП.

Для достижения указанной чели использованы следующие методы исследования: теоретический анализ и синтез основных положений психолого-педагогической науки по проблеме возникновения и профилактики синдрома госпитализма у детей раннего возраста с ДЦП; изучение психологических основ профилактической работы с детьми раннего возраста с детскими церебральными параличами; систематизация результатов научно-теоретического анализа особенностей профилактической работы с детьми раннего возраста с ДЦП.

Результаты исследования. Выяснено, что первичная профилактика предполагает активную работу с детьми раннего возраста с детскими церебральными параличами до появления симптомов госпитализма с целью предотвращения его возникновения. Вторичная профилактика включает в себя работу команды специалистов различных профилей, направленную на предупреждение обострения госпитализма у детей, имеющих его проявления. Третичная профилактика направлена на предупреждение повторного возникновения синдрома госпитализма на фоне восстановления познавательной и социальной активности детей раннего возраста с ДЦП. В соответствии с задачами исследования построена модель системы профилактики синдрома госпитализма у детей раннего возраста с ДЦП, выделены направления, условия и сферы (c) Rudenko Liliia, Sniatkova Tetiana

DOI (article): https://doi.org/10.32626/2227-6246.2021-53.235-257 http://journals.uran.ua/index.php/2227-6246 
DOI: https://doi.org/10.32626/2227-6246.2021-53

2021. ВИПУСК 53

реализации мероприятий первичной, вторичной и третичной профилактики. В процессе обоснования системы профилактики указано, какими специалистами различных профилей выполняются основные направления деятельности в рамках первичной, вторичной и третичной профилактики синдрома госпитализма у детей раннего возраста с детскими церебральными параличами.

Выводы. Основным условием успешности системы профилактики госпитализма у детей раннего возраста с ДЦП является систематический подход к ее проведению, последовательная реализация задач первичной, вторичной и третичной профилактики.

Ключевые слова: госпитализм, дети раннего возраста, детский паралич, профилактическая работа, ранний возраст.

Original manuscript received April 10, 2021

Revised manuscript accepted May 24, 2021 